\title{
A Brief Note on Women Characters in Toni Morrison's Fiction
}

\author{
V. Beulah Rani \\ Lecturer in English, Hindu College, Guntur \\ Ch. Aruna \\ Lecturer in English, Hindu College, Guntur
}

\begin{abstract}
Toni Morrison is an American author, editor, professor who got Pulitzer Prize for her fiction beloved in 1998. She is the first black women to receive Nobel Prize in literature in 1993. Toni Morrison's original name is Chloe Anthony Wofford. She grew up in an American family that possessed an intensive love and appreciation for black culture. Morrison's novel characterized by visionary force and poetic import gives life to an essential aspect. She is pioneer in Black feminism. In her writings we see black women to love themselves, their race and their culture and not to trap in white superiority or white beauty standards.

The present article attempts to examine major character's ways of forming self - concept in the face of racism. It also attempts to show that those black female characters of Toni who follow womanistic ideas manage to cope with their problems and eventually survive.
\end{abstract}

Keywords: Feminism, Political, Black, Slaves, Psychology.

\section{INTRODUCTION}

Toni Morrison is an American novelist, editor and professor emeritus at Princeton University. Her novels are known for their epic themes, vivid dialogue and richly detailed characters. Her best known novels are The Bluest Eye (1970), Sula (1973), Song of Solomon (1977) and Beloved (1987).

Morrison began writing fiction as a part of informal group of poets \& writers at Howard University. In addition to her novels, Morrison has written books for children with her younger son, Slade Morrison. Her novels are typically concentrated on black women.

"You educate a man; you educate a man you educate a woman; you educate a generation" - Brigham young.

"He is a gentleman, and I am a gentle man's daughter. So far we are equal.

Jane Austen.

Feminism is an entire world view or gestalt, not just a laundry list of women's issues. It is a movement for granting women political, social and economic equality with men, i.e., seeking to establish equal opportunities for women in education and employment.

Morrison is an African-American woman. The inscription of looking relations in her novels the Blest Eye, Sula, Song of Solomon, Tar Baby and Beloved assumes boundaries that encompasses several objectifications of women. Understood from the perspective of a black woman, the dominant society's gaze, construed as white and male, is driven by a layering of motivations that express not only sexual objectification but also racism and classism in its operations.

Morrison's first book, The Bluest Eye (1970) is a novel of initiation concerning a victimized adolescent black girl who is obsessed by white standards of beauty and longs to have blue eyes.

Her second novel sula (1973) examines the dynamics of friendship and the expectations for conformity within the community. Song of Solomon (1977) brought Morrison to national attention. Tar Baby (1981) set on a Caribbean island, explores conflicts of race, class and sex. 
The Beloved (1987) which won a Pulitzer prize for fiction is based on the true story of a runaway slave who, at the point of recapture, kills her infant daughter to order to spare her a life of slavery. Jazz (1992) is a story of violence in Newyork City. Paradin (1998) is a story sure to generate volumes of feminist appraisal. It is a richly detailed portrait of a black utopian community in Oklahoma. Love (2003) an intricate family story that reveals the myriad facets of love and its ostensible opposite. A mercy (2008) deals with slavery in $17^{\text {th }} \mathrm{C}$ America. Home (2012) a traumatized Korean war. Veteran encounters racism after returning home and later overcomes apathy to rescue his sister.

The Bluest Eye holds, its central concern, as a critique of Western Beauty and its special destructiveness when imposed upon people of color in general and women of color in particular. A twelve year old black girl is the poignant victim named Pecola Breelove.

In Sula Morrison shifts her focus on "the look" to exploring the actions of her characters the ethical difference between the very "to see" and "to watch". In Sula black folk community interrogate modes of "the look" within their system of valves. In this novel Morrison asserts the pattern of self discovery.

Morrison's Song of Solomon recognizes that under patriarchy the female gaze into the mirror confirms a sense of lack or self-negation. For through the workings of narcissism and exhibitionism the mirror gaze entraps woman as the displayed object of male desire. It is precisely because woman in the consumer system bears the burden of several and gender focused exploitation that rushes off to obtain mad list of commodities and beauty treatments in order to transform herself into the objectified spectacle worthy of male attention and romance.

As a high-fashioned model raised in a white wealthy household that is completely isolated from the black community which in some manner asserts itself in the verisimilitude of Morrison's novels. Jadine is considered as individualist careerist. However Jadine's admiring gaze at this "unphotographable beauty is returned with the counter hegemonic look" of resistance and rejection. Her professional exhibitionism signals her construction as the reified and a result of trajectory of situations, characters and attitudes that critique and explore "the look" in its varied modalities throughout Morrison's first four novels.

Morrison divided Beloved into three books each book is divided into sections. Beloved is not narrated chronologically. It is composed of flashbacks, memories and nightmares. It is a moving debut novel which paints a vivid portrait of both the beauty and the burden of slavery.

Beloved explores the physical, emotional and spiritual devastation wrought by slavery, a devastation that continues to haunt those characters who are former slaves even in freedom

Salves were told they were subhuman and were traded as commodities whose worth could be expressed in dollars. Paul D, for instance is so alienated from himself that at one point he cannot tell whether the screaming he hears is his own (or) someone else's. Sethe, once walked in on school teacher giving his pupils a lesson on her animal characteristics was also treated as a subhuman. In beloved, we learn about the history and legacy of slavery. Morrison writes history with the voices of a people historically denied the power of language. Beloved recuperates a history that had been lost either due to willed forgetfulness or to forced silence. Beloved demonstrates the extent to which individuals need to support of their communities in order to survive. Morrison enhances the world of beloved by investing it with a supernatural dimension. Toni's paradise (1998) according to her completes a trilogy that begins with beloved and includes Jazz. As it was her first novel since she was awarded Nobel Prize in literature in 1993 it was chosen as an oprah's book club selection on January 1998.

It addresses the same great themes of her masterpiece beloved - the loss of innocence, the paralyzing power of ancient memories and the difficulty of accepting loss and change and pain.

It, too, deals with the blighted legacy of slavery, examines the emotional and physical violence the human beings are capable of inflicting upon one another. It suggests that the redemption is to be found not obsessively remembering the past but in letting go. It's a heavy - handed, schematic piece of writing thoroughly lacking in the novelistic magic Ms. Morrison has wielded so effortlessly in the past.

Toni Morrison suggests that she chooses subjects that interests her and not that are popular with readers and publishers. Sociology, Polemics, Sadist themes do not concern Morrison who aims to 
express a cultural legacy. She wants her novels to have an oral effortless quality evoking the tribal story telling tradition of the African grist who resides the legendary events of generations.

Her characters too, should have a special essence and they should be ancestral and enduring. Her vision creates extra-ordinary tales of human experience, which a less independent writer would perhaps not attempt to. This is not to suggest that her fiction indicates a sort of displays or sort of selfgratification. In this context her novels are not just for out arts sale but they are political as well. In fact she says the best art is political. She believes her novels are instruments for transmitting cultural knowledge not just a closed exercise of her imagination, which meets the obligation of her personal dreams.

Morrison's chief strategy for achieving this goal is to integrating life and by anchoring her fiction in the folk way that rhythms African-American communal life. Morrison thoroughly integrates folk passions into her fiction.

From the beginning of her writing, she has exercised a keen scrutiny of her woman's life. "The Bluest Eye" and "Sula" her first and second novels to some varying extents, they are about the black girlhood and womanhood Women's connections to their families, to their communities, to a larger social net work outside the community, to men and to each other.

In the "Bluest Eye" she is interested in talking about black girlhood and in Sula she goes to the other part of life. The "Bluest Eye" directs a critical gaze at the process and symbols of imprinting the self during childhood and what happens to. the self when the process is defective.

In "Sula", Morrison builds on the knowledge gained in the novel and revisits childhood and then moves her characters and readers a step forward unto Women's struggles to change, de-limiting symbols and take control of their lives and at sometime she demonstrates in Sula although re-casting one's role in the community is possible, though there is a price to be paid for change.

In the "Bluest Eye" Blue eyes are Pecola's unfulfilled dream. The tangible Shirley Temple doll with which the girls play has blue eyes. The image remains in some way, like a painfully blinding light and an instrument of fortune throughout the novel. Pecola is sexually assaulted by his father, this makes her longing intensified when Pecola is driven further into escapism. It is a lesson to the innocent children who must learn to look beyond themselves for fulfillment.

In the "Bluest Eye" Morrison depicts the contrastive view of life. Morrison underscores the dilemma with which the black child had to undergo to make believe world of which he had no part and the world which he was all too familiar.

The ability to create in some characters does not prevent the extreme psychological dilemmas, which lead to insanity. Thus insanity is a form of the grotesque in all four novels. Morrison's insane characters often have painfully authentic insights. In the Bluest Eye, Pecola's unreasonable wish to have blue eyes is a capitulation to the demands of an unfair society, which acknowledges only Caucasian beauty, in the same novel, Soap Head's irrational behavior is his intellectual response to the absurdity of life.

Discussing "The Bluest Eye" she explains that in writing it she breaks a silence of the Black community. She as an individual writer articulated or gave voice to the Black experience which until now was hidden, repressed and secreted. She explains her technique of narration as that used in telling gossip in undertone, that which is scandalous and revealing.

In the first chapter Claudia's narrative retrospective of her childhood describes a world "adults don't talk to us but they give us directions. They issue orders without providing information. Here Morrison makes us immersed in Claudia's childhood, we perceive through the eyes of a child. Morrison wonderfully describes the situation and her reminiscences are split between a child's and adults' view point and thus she vacillates from personal subjectivity to an objective recognition that serves to emphasize the difficulty in sorting through her feelings for herself friends after her world around her. It is girlhood psychological feeling expressed.

White beauty, white living white freedom, these are what the characters of in "The Bluest Eye" long for, strive for and yet can never realize. 
Toni Morrison's novel "Sula" is an exploration of creativity in Afro-American fiction. It has, strong bearing of female potential. "Sula" the character is created with an independent thinking and solidarity. It is an outcome of their suffering and exploitation by while society "Sula" the character conveys new psychological trends.

"Sula" the third generation of man loving women is given in the novel Sula which removes her from the ordinary people of Medallion. With her independent thinking she says 'she wants to make herself instead of marriage and bringing children. She breaks out the bonds of her small town. Nel and Sula are drawn to each other. Their togetherness enhances their understanding of the divergent ways their lives makes them closes. When they are grownup they realize the whites and Male's who have freedom and triumph is forbidden to them. Sula is an unconventional, patriarchal character.

The three incidents in Sula's life indicates the Sula's psyche and its development. Morrison creates the two characters Sula and Nel one with wildness and another with submissiveness, which strike a balance of an individual.

In "Sula" the feminine psychology is explored to an extreme individuality and as a negative aspect of self. In the "Bluest Eye" it is only a girlhood and childhood experiences. But in Sula more matured and show that the unrecognized dark half of the personalities can create havoc. Here it is a vital point that one has to recognize both negative and positive sides, the happy and sorrowful situation which is a must for totality of the self.

Violet is an example of self-discovery. Self-discovery leads to courage, honesty and conviction.

Deep rooted adherence to patriachal values made black resent their women fighting for recognition for their equality. They feared that black women's movement might weaken the causes of black race as a whole Black Women had flight against both. A Black Feminist statement released in 1974 says: "We struggle with black men against racism, while we also struggle against black men about sexism".

Through the characters of Nel and Sula, Morrison conveys a message on what model of individualism a black women should develop and in what way she should strive for a successful quest for self. In 'Sula' she has created Nel and Sula two different women with different psychologies and almost divergent models of conformity and non-conformity, define their personalities is to define half of an individual.

Sula is a rebel, individualistic with highly independent thinking. She goes according to her own views of inner being but she has to pay price for her extreme thinking which "bottom" could not accept. She refuses to be ruled by stultifying values traditionally and blindly followed by the community. But Nel acquires the exciting style of Women's role, which is endorsed and prescribed by the community.

Morrison illustrates the two women with a difference, which is merely superficial and in a way both are complementary to each other. Their togetherness brings a complete entity. Their friendship produces and strengthens their views about their own self and each one finding the other in a more convictional way Their friendship gives homage to take life arid accept day to day struggles and also defy mother's dictatorship.

In the presence of Nel, Sula gets desire to her own self and unconsciously to be traditional and irresponsible yearning for freedom. She always wishes to be wonderful. She says "Oh! Jesus makes me wonderful".

Sula is very individualistic and tells her grandmother that she is not interested in marriage and producing children that is in making others instead of that "she desires to make herself".

"If I can do that to myself what you suppose, I'll do it to you". "Self" guarding is Sula's quality inherited from her grandmother. Eva Peace the novel represents 'Sula' is a rash and wild natured. Nel with a stable mind and Sula a daring and dashing one Hannah Sula's mother is a quality of indifferent. Eva's arrogance prevents her for children from realizing the value of her sacrifice.

"The Bluest Eye" is the beginning of a girl's psychology and Sula is about Motherhood and girlhood at a matured level. Toni Morrison writes in her creative way and a more grading order.

Toni Morrison's master work song of Solomon's, the greatest novel ever written by an Afro-American begins the novel clearly reveals the disparate and extremely couple ways Afro-Americans have thought about the quality of their lives. Milkman Dead in a middle class protagonist of Solomon. 
Their Socio-Economic differences consequential socializations and their divergent experience are a microcosm for the two most distinguishable Afro-American ideological streams. Milkman Dead completes a heroic quest for identity and place with community.

Early in the novel a pattern develops which shows that women exist for males as mere operatives. Mothers and lovers live for and linger in the presence and absence of dead fathers, Dead husbands' and in different male lovers They appear like Milkman, as passive victims they convey understanding and guidance, and even like Pilate, they appear as free-flyers who project a self-sustaining image. But never does their alienation their awareness or their apparent freedom lead to a positive engagement with the community. They remain denatured disengaged and are even killed off. No matter how similar they appear they lack Milkman's possibilities they play no central role. Their dreams if they have at all, remain in fulfilled until the male here fulfills them.

As Simone Beauvior says if women in her the second sex, the women in song of Solomon "still dream through the dreams of men". The lack of full and equal participation in heroic models of myth and history is clearly and consciously illustrated through the character of Pilate like Sula, Pilate's story indicates that she possesses the essences of the existential male hero.

Pilate has overcome great odds and obstacles, she has been a woman alone who raises and provide for a family. She lives the life of an archetypal "running man" whose vision of progress is encompassed in the physical actualizations of her geography book.

Pilate embodies the spiritual resources of African-American folk traditions she appears as a kind of supernatural character an earth mother, a voodoo priestess and contour a mythical story letter. In everyday world, her lack of novel marks her as unnatural.

Paradoxically, in Pilate's' death we are left with an image of Pilate that offers the only definitive transcendence in the novel. She is the one character, who in spite of her physical restlessness and isolation, has been able to strike a balance and resolve the conflict between a personal and a collective consciousness she lived life of honesty and equilibrium Pilate's spirit continues to soar through Milkman.

\section{CONCluSion}

One of the central issues before Toni Morrision as before most Black - American writers is the question of self - identity basing black life and experience Morrison works to explore tragic results for Blacks especially when they accept values of middle class whites but they also show that the results are the same when female Black characters define themselves according to the standard and desires of the men they love Her novel Tar Baby occupies a special place among her works. It not only gives a fair idea of how she defines herself in a way radically different from most others of her community but also shows how her self-definition enables her to relate meaningfully to people of all ideological persuasions.

Her women characters are cooks, mothers, wives and lovers. All the characters reveal her outlook of humanity Jadine is the images of detachment, evil and indecision pervade the novel and remain fixed presences throughout.

Jadine orphaned and she is portrayed in the story as the epitome of "get-set" character - beautiful, intelligent refined and ambitious. Margaret is a beautiful woman separated from the family. Unlike, Sula or Pilate Margaret's difference actually denies the potential for freedom because it has long been culturally institutions lazed, frozen in place as it were her difference obscures her social and emotional vulnerabilities and leaves her eviled from an epitaphic human community.

Her quest to a Black self is reflected in her first novel The Bluest Eye In terms of Morrison's quest to inscribe the black figure on the white page, to raise her character's out of the black whole, the Bluest Eye can be seen as a direct confrontation with the white logos. In Sula she attempts to move her focus outside the sphere of influence of the white logos by centering novel around a black community. In Song of Solomon community continues her ongoing quest to free herself and her characters from the imperialism of the white logos. Toni Morrison recognizes that under patriarchy the female gaze into the mirror confirms a sense of lack or self - negation. In "Tar Baby" woman figured in the character Jadine, totally depicted as the narcissistic exhibitional and commoditized. 


\section{REFERENCES}

[1] Beloved - Toni Morrison.

[2] Song of Solomon - Toni Morrison.

[3] Durall, John N (2000) - The Identifying Fictions of Toni Morrison; Modernist Authenticity and post modern Blackness.

[4] Black writers in praise of Toni Morrison - The New York Times.

[5] The Bluest Eye (1970) - Toni Morrison.

[6] Paradin (1998) - Toni Morrison.

[7] Sula (1973) - Toni Morrison.

[8] “The Bluest Eye at oprah's Book club official page” Oprah.com.

[9] Hevesi Dennis “Toni Morrison's novel 'Beloved' wins the Pulitzer prize in Fiction" The New York Times

\section{AUTHORS' BIOGRAPHY}

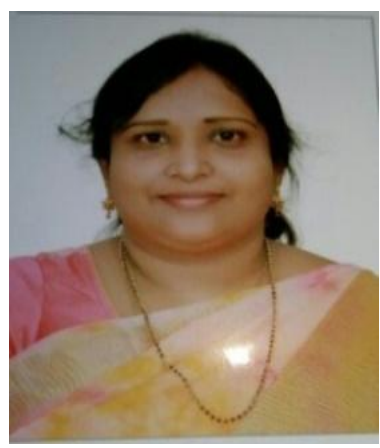

Velpula Beulah Rani, have been in service as a Lecturer in English in this August body since 2000. I have enriched my teaching and language skills by participating in various National and International seminars and workshops. Eight of my research articles have been published in different souvenirs. Three of my research articles have been published in international souvenirs.

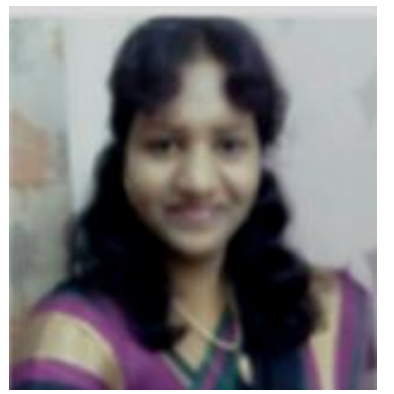

Chilka Aruna, is a Lecturer in English have been rendering services to the prestigious institution Hindu College, Guntur since 2000. In 2008, I became the Head of the Department. Coming to my personal profile, I have been awarded the A.P.STATE BEST TEACHER AWARD in 2015. Twelve of my research articles have been published in different souvenirs. I feel proud to say that I have been awarded the GURU BRAHMA NATIONAL AWARD-2016 by the MOTHER THERESA SOCIAL WELFARE ORG. (Regd.No:649/2010) in the year 2016. I have participated in various National \& International seminars and workshops. Thus I have enriched my language skills as well as teaching skills. Once again I feel proud to say that I have exchanged my views regarding literature and language with popular literary figures and experts in communication skills. 